\title{
HUBUNGAN TINGKAT PENDIDIKAN DAN TINGKAT PENGETAHUAN TENTANG KESEHATAN JIWA DENGAN SIKAP MASYARAKAT TERHADAP PASIEN GANGGUAN JIWA DI RW XX DESA DUWET KIDUL, BATURETNO, WONOGIRI
}

\author{
Tunjung Sri Yulianti ${ }^{1}$, Wulan Meilina Putri Wijayanti ${ }^{2}$
}

\begin{abstract}
Introduction: management of mental health problems require complex handling. This of course must involve all parties. Mental patients who have recovered will be returned to the family and society. This requires the readiness of families and communities. During this time in the community or family is still found the response and understanding is not correct to mental patients, but their role is crucial to the recovery of patients with mental disorders.

Purpose of the study: To determine the relationship between the level of education and level of knowledge about mental health and community attitudes towards mental patients in RW XX Duwet Kidul Baturetno, Wonogiri .

Subjects: were people in RW XX Duwet Kidul, Baturetno, Wonogiri aged adults (18-60 years ) some 108 people taken at random by the table Krecjie

This research method is correlation study involving the three variables, the first variable is the level of education, the second variable is the level of knowledge and the third variable is the attitude of society, with logistic regression statistical test.

Results: of the study obtained Nagelkerke R Square value of 0.279 .

Conclusion The study each variable is jointly influence public attitudes against mental patients was $27.9 \%$, while the remaining $72.1 \%$ is influenced by other variables attitude.
\end{abstract}

Keywords: Education Level, Level of Knowledge, Attitudes Society

\section{PENDAHULUAN}

Lingkup masalah kesehatan jiwa yang dihadapi individu sangat kompleks sehingga perlu penanganan oleh suatu program kesehatan jiwa yang bersifat kompleks pula. Masalah-masalah kesehatan jiwa dapat meliputi : perubahan fungsi jiwa sehingga menimbulkan penderitaan pada individu (distres) dan atau hambatan dalam melaksanakan fungsi sosialnya, masalah psikososial yang diartikan sebagai setiap perubahan dalam kehidupan individu baik yang bersifat psikologis maupun sosial yang memberi pengaruh timbal balik dan dianggap mempunyai pengaruh cukup besar. Sebagai faktor penyebab timbulnya berbagai gangguan jiwa. Keadaan ini disebut stres psikososial yang dapat berupa masalah perkembangan manusia yang harmonis, peningkatan kualitas hidup, upaya-upaya kesehatan jiwa diperlukan untuk mengatasi masalah tersebut diatas yang meliputi upaya primer, sekunder dan tersier yang ditujukan untuk meningkatkan taraf kesehatan jiwa manusia agar dapat hidup lebih sehat, harmonis dan produktif. (Suliswati, et al., 2005)

Paparan di atas menyatakan bahwa penatalaksanaan masalah kesehatan jiwa memerlukan penanganan yang kompleks. Hal ini tentu saja harus melibatkan semua pihak. Pasien gangguan jiwa yang 
telah pulih akan kembali kepada keluarga dan masyarakat. Sementara orang-orang yang mengalami masalah kesehatan jiwa yang belum sampai rawat inap di rumah sakit juga semakin banyak, dan mereka tinggal di dalam keluarga dan di sebuah masyarakat. $\mathrm{Hal}$ ini memerlukan kesiapan keluarga dan masyarakat dalam mensikapi kondisi mereka. Dituntut pengetahuan, sikap dan tindakan yang benar dalam merawat mereka agar bisa kembali berfungsi dengan baik, dan pasien yang belum sampai dirawat di rumah sakit agar gangguan kesehatan jiwanya tidak semakin memberat.

Selama ini di masyarakat atau keluarga masih banyak ditemukan respon dan pemahaman yang belum benar terhadap pasien gangguan jiwa, padahal peran mereka sangat penting terhadap kesembuhan pasien gangguan jiwa. Masih ada pemikiran di masyarakat bahwa pasien gangguan jiwa adalah seseorang yang mengancam dan harus dijauhi, hal ini menyebabkan pasien gangguan jiwa tidak memperoleh dukungan dan perawatan yang memadai sehingga memungkinkan untuk kambuh.

Salah satu warga di Desa Duwet Kidul ada yang terganggu jiwanya dan sering kali kambuh jika dia terlalu stres dan mempunyai beban pikiran yang berat. Berdasarkan survey dan wawancara yang dilakukan terhadap 10 orang warga yang tinggal di Desa Duwet Kidul Kabupaten Wonogiri, terdapat 5 orang yang mengatakan bahwa warga yang terganggu jiwanya tersebut adalah orang gila yang harus dihindari karena mereka berbahaya bagi orang lain dan bisa mengamuk kapan saja dan menyakiti warga, 4 orang mengatakan takut karena anak-anak mereka yang bermain sering diganggu dan kadang-kadang berkata kasar serta jorok yang tidak baik bagi anak-anak dan 1 orang mengatakan bahwa sebenarnya warga yang mengalami gangguan jiwa tersebut jangan dimusuhi karena mereka juga manusia, tetapi mereka hanya sedang mengalami stress saja.

Berdasarkan uraian di atas maka peneliti tertarik untuk melakukan penelitian yang berjudul "Hubungan antara Tingkat Pendidikan dan Tingkat Pengetahuan Tentang Kesehatan Jiwa dengan Sikap Masyarakat terhadap Pasien Gangguan Jiwa di RW XX Desa Duwet Kidul, Kecamatan Baturetno, Kabupaten Wonogiri".

\section{TUJUAN PENELITIAN}

1. Menganalisa hubungan tingkat pendidikan dengan sikap masyarakat terhadap pasien gangguan jiwa di Desa Duwet Kidul, Kecamatan Baturetno, Kabupaten Wonogiri

2. Menganalisa hubungan tingkat pengetahuan dengan sikap masyarakat terhadap pasien gangguan jiwa di Desa Duwet Kidul, Kecamatan Baturetno, Kabupaten Wonogiri

\section{DESAIN PENELITIAN}

Penelitian ini merupakan penelitian analitik dengan desain penelitian korelasional. Melibatkan tiga variabel, variabel bebas atau variabel independent pertama adalah tingkat pendidikan, variable bebas kedua adalah pengetahuan masyarakat tentang kesehatan jiwa. Variabel yang ketiga adalah sikap masyarakat terhadap pasien gangguan jiwa sebagai variabel terikat atau variabel dependent. Uji statistic yang digunakan adalah $\mathrm{Uji}$ Chi Kuadrat dan Uji Regresi Logistik dengan bantuan program SPSS for Windows Seri 18. 
POPULASI, SAMPEL, DAN TEHNIK SAMPLING

Populasi pada penelitian ini adalah seluruh masyarakat RW XX, Desa Duwet Kidul, Kecamatan Baturetno, Kabupaten Wonogiri yang berusia dewasa (18-60 tahun) berjumlah 150 orang. Sampel penelitian adalah 108 orang diambil berdasarkan tabel KRECJIE. Pemilihan sampel dipilih melalui undian atau sesuai nomor secara acak.

\section{HASIL PENELITIAN}

Penelitian ini dilakukan pada bulan September tahun 2015 sampai dengan Maret 2016 dengan jumlah responden 108 orang yaitu masyarakat yang berusia dewasa (18 - 60 tahun) di RW XX Desa Duwet Kidul, Kecamatan Baturetno, Kabupaten Wonogiri.

Karakteristik responden

1. Berdasarkan jenis kelamin

Tabel 1

\begin{tabular}{ccc}
\hline $\begin{array}{c}\text { Jenis } \\
\text { Kelamin }\end{array}$ & $f$ & $(\%)$ \\
\hline Laki-laki & 38 & 35 \\
\hline Perempuan & 70 & 65 \\
\hline Jumlah & 108 & 100 \\
\hline
\end{tabular}

Dari tabel di atas diperoleh informasi bahwa 38 responden (35 \%) laki-laki dan 70 responden (65\%) adalah perempuan.

2. Berdasarkan jenis pekerjaan

Tabel 2

\begin{tabular}{ccc}
\hline $\begin{array}{c}\text { Jenis } \\
\text { Pekerjaan }\end{array}$ & $\mathrm{f}$ & $(\%)$ \\
\hline Petani & 1 & 0,93 \\
\hline Pedagang & 25 & 23,14 \\
\hline Karyawan & 25 & 23,14 \\
\hline PNS & 6 & 5,56 \\
\hline Mahasiswa & 5 & 4,64 \\
\hline Pelajar & 7 & 6,48 \\
\hline Buruh & 7 & 6,48 \\
\hline Tidak bekerja & 32 & 29,63 \\
\hline Jumlah & 108 & 100 \\
\hline
\end{tabular}

Dari tabel di atas diperoleh informasi bahwa jumlah responden yang terbanyak adalah tidak bekerja yaitu 32 orang $(29,63 \%)$, berikutnya adalah pedagang yaitu 25 orang $(23,14 \%)$ dan karyawan sebanyak 25 orang $(23,14 \%)$.

3. Tingkat pendidikan

Tabel 3

\begin{tabular}{ccc}
\hline $\begin{array}{c}\text { Tingkat } \\
\text { Pendidikan }\end{array}$ & $\mathrm{f}$ & $(\%)$ \\
\hline Tinggi & 77 & 71,3 \\
\hline Rendah & 31 & 28,7 \\
\hline Jumlah & 108 & 100 \\
\hline
\end{tabular}

Dari tabel di atas dapat diketahui bahwa sebagian besar responden berada pada tingkat pendidikan tinggi yaitu 77 orang $(71,3 \%)$, sedangkan 31 orang $(28,7 \%)$ berada pada tingkat pendidikan rendah.

4. Tingkat pengetahuan masyarakat tentang kesehatan jiwa

Tabel 4

\begin{tabular}{ccc}
\hline $\begin{array}{c}\text { Tingkat } \\
\text { Pengetahuan }\end{array}$ & $f$ & $(\%)$ \\
\hline Tinggi & 94 & 87 \\
\hline Rendah & 14 & 13 \\
\hline Jumlah & 108 & 100 \\
\hline
\end{tabular}

Dari tabel di atas dapat diketahui bahwa sebagian besar responden yaitu 94 orang (87\%) mempunyai tingkat pengetahuan yang tinggi tentang kesehatan jiwa dan 14 responden (13\%) mempunyai tingkat pengetahuan yang rendah tentang kesehatan jiwa. Berdasarkan analisa univariat tingkat pengetahuan tentang kesehatan jiwa diperoleh hasil nilai Mean adalah 47,31. Sehingga rata-rata tingkat pengetahuan tentang kesehatan jiwa masyarakat termasuk dalam kategori tinggi. 
5. Sikap masyarakat terhadap pasien gangguan jiwa

Tabel 5

\begin{tabular}{ccc}
\hline $\begin{array}{c}\text { Sikap Terhadap } \\
\text { Pasien } \\
\text { Gangguan Jiwa }\end{array}$ & $\mathrm{f}$ & $(\%)$ \\
\hline Positif & 87 & 80,6 \\
\hline Negatif & 21 & 19,4 \\
\hline Jumlah & 108 & 100 \\
\hline
\end{tabular}

Dari tabel di atas dapat diketahui bahwa sebagian besar responden yaitu 87 orang $(80,6 \%)$ mempunyai sikap yang positif terhadap pasien gangguan jiwa dan ada 21 responden $(19,4 \%)$ yang mempunyai sikap negatif terhadap pasien gangguan jiwa. Berdasarkan analisa univariat sikap masyarakat terhadap pasien gangguan jiwa diperoleh hasil nilai Mean adalah 15,76. Sehingga rata-rata sikap masyarakat terhadap pasien gangguan jiwa adalah positif.

6. Hubungan tingkat pendidikan dengan sikap masyarakat terhadap klien gangguan jiwa

Tabel 6

\begin{tabular}{cccc}
\hline \multirow{2}{*}{$\begin{array}{c}\text { Tingkat } \\
\text { Pendidik } \\
\text { an }\end{array}$} & \multicolumn{2}{c}{$\begin{array}{c}\text { Sikap } \\
\text { Masyarakat }\end{array}$} & \multirow{2}{*}{$\begin{array}{c}\text { Jum } \\
\text { lah }\end{array}$} \\
\cline { 2 - 3 } & $\begin{array}{c}\text { Posi } \\
\text { tif }\end{array}$ & $\begin{array}{c}\text { Nega } \\
\text { tif }\end{array}$ & \\
\hline Tinggi & 69 & 8 & 77 \\
\hline Rendah & 18 & 13 & 31 \\
\hline Jumlah & 86 & 21 & 108 \\
\hline
\end{tabular}

Dari tabulasi silang di atas diperoleh informasi sebagai berikut : responden yang mempunyai pendidikan tinggi dengan sikap yang positif sebanyak 69 orang dan yang memiliki sikap negatif sebanyak 8 orang. Sedangkan responden yang memiliki tingkat pendidikan rendah dengan sikap yang positif sebanyak 18 orang dan yang memiliki sikap negatif sebanyak 13 orang.
Tabel 7

\begin{tabular}{lccc}
\hline Value & Df & $\begin{array}{c}\text { Asymp. } \\
\text { Sig. } \\
(2-\text {-sided })\end{array}$ & $\begin{array}{c}\text { Exact } \\
\text { Sig. } \\
(2-\text {-sided })\end{array}$ \\
\hline $\begin{array}{l}\text { Pearson } \\
\text { Chi- } 14,042^{\mathrm{a}}\end{array}$ & 1 &, 000 & \\
Square & & & \\
\hline $\begin{array}{l}\text { Fisher's } \\
\text { Exact } \\
\text { Test }\end{array}$ & & &, 001 \\
\hline
\end{tabular}

Dari tabel di atas dapat dilihat bahwa nilai significancy dari Pearson Chi Square yang diperoleh adalah 0,000. Dengan demikian dapat diketahui bahwa ada hubungan antara tingkat pendidikan dengan sikap masyarakat terhadap pasien gangguan jiwa sehingga hipotesa pertama diterima.

7. Hubungan tingkat pengetahuan tentang kesehatan jiwa dengan sikap masyarakat terhadap klien gangguan jiwa

Tabel 8

\begin{tabular}{cccc}
\hline \multirow{2}{*}{$\begin{array}{c}\text { Tingkat } \\
\text { Pengetah } \\
\text { uan }\end{array}$} & \multicolumn{2}{c}{$\begin{array}{c}\text { Sikap } \\
\text { Masyarakat }\end{array}$} & $\begin{array}{c}\text { Jum } \\
\text { lah }\end{array}$ \\
\cline { 2 - 4 } tif & $\begin{array}{c}\text { Nega } \\
\text { tif }\end{array}$ & \\
\hline Tinggi & 82 & 12 & 94 \\
\hline Randah & 5 & 9 & 14 \\
\hline Jumlah & 87 & 21 & 108 \\
\hline
\end{tabular}

Dari tabulasi silang di atas diperoleh informasi sebagai berikut : responden yang mempunyai tingkat pengetahuan tinggi dengan sikap yang positif sebanyak 82 orang dan yang memiliki sikap negatif sebanyak 12 orang. Sedangkan responden yang memiliki tingkat pengetahuan rendah dengan sikap yang positif sebanyak 5 orang dan yang memiliki sikap negatif sebanyak 9 orang. 
Tabel 9

\begin{tabular}{ccccc}
\hline & Value & Df & $\begin{array}{c}\text { Asymp. } \\
\text { Sig. (2- } \\
\text { sided) }\end{array}$ & $\begin{array}{c}\text { Exact Sig. } \\
\text { (2-sided) }\end{array}$ \\
\hline $\begin{array}{c}\text { Pearson } \\
\text { Chi-quare }\end{array}$ & $20,649^{\mathrm{a}}$ & 1 &, 000 & \\
\hline $\begin{array}{c}\text { Fisher's } \\
\text { Exact Test }\end{array}$ & & &, 000 \\
\hline
\end{tabular}

Dari tabel di atas dapat dilihat bahwa nilai significancy dari Pearson Chi Square yang diperoleh adalah 0,000. Dengan demikian dapat diketahui bahwa ada hubungan antara tingkat pengetahuan tentang kesehatan jiwa dengan sikap masyarakat terhadap pasien gangguan jiwa sehingga hipotesa kedua diterima.

8. Hubungan tingkat pendidikan dan tingkat pengetahuan tentang kesehatan jiwa dengan sikap masyarakat terhadap klien gangguan jiwa.

Tabel 10

\begin{tabular}{ccccc}
\hline \multirow{2}{*}{$\begin{array}{c}\text { Sikap } \\
\text { Masya } \\
\text { rakat }\end{array}$} & \multicolumn{2}{c}{$\begin{array}{c}\text { Tingkat } \\
\text { Pendidik } \\
\text { n }\end{array}$} & \multicolumn{2}{c}{$\begin{array}{c}\text { Tingkat } \\
\text { Penge } \\
\text { tahuan }\end{array}$} \\
\cline { 2 - 5 } ging & $\begin{array}{c}\text { Ren } \\
\text { dah }\end{array}$ & $\begin{array}{c}\text { Ting } \\
\text { gi }\end{array}$ & $\begin{array}{c}\text { Ren } \\
\text { dah }\end{array}$ \\
\hline $\begin{array}{c}\text { Posi } \\
\text { tif }\end{array}$ & 69 & 18 & 82 & 5 \\
\hline $\begin{array}{c}\text { Nega } \\
\text { tif }\end{array}$ & 8 & 13 & 12 & 9 \\
\hline $\begin{array}{c}\text { Jum } \\
\text { lah }\end{array}$ & 77 & 31 & 94 & 14 \\
\hline
\end{tabular}

Dari tabulasi silang di atas diperoleh informasi sebagai berikut : responden yang mempunyai tingkat pengetahuan tinggi dengan sikap yang positif sebanyak 82 orang dan yang memiliki sikap negatif sebanyak 12 orang. Sedangkan responden yang memiliki tingkat pengetahuan rendah dengan sikap yang positif sebanyak 5 orang dan yang memiliki sikap negatif sebanyak 9 orang.
Dari analisa regresi logistik yang dilakukan diperoleh hasil sebagai berikut :

Tabel 11

\begin{tabular}{cccc}
\hline Step & $\begin{array}{c}-2 \text { Log } \\
\text { likeli } \\
\text { hood }\end{array}$ & $\begin{array}{c}\text { Cox \& Snell } \\
\text { R Square }\end{array}$ & $\begin{array}{c}\text { Nagelkerke } \\
\text { R Square }\end{array}$ \\
\hline 1 & $85,647^{\mathrm{a}}$ &, 175 &, 279 \\
\hline
\end{tabular}

Dari hasil uji statistik multivariat pada tabel diatas dapat dilihat bahwa terdapat hubungan antara tingkat pendidikan dan tingkat pengetahuan dengan sikap masyarakat pada pasien gangguan jiwa yang ditunjukkan dengan nilai Nagelkerke $R$ Square 0,279 atau 27,9\%.

Tabel 12

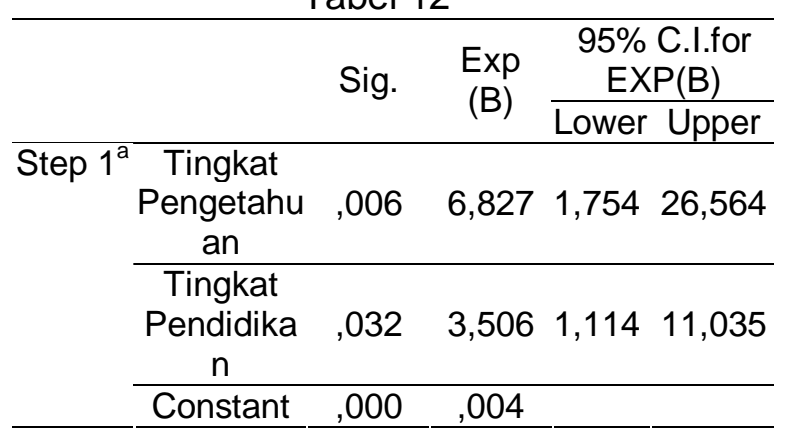

\section{PEMBAHASAN}

1. Karakteristik Responden Berdasarkan data karakteristik responden, diperoleh informasi bahwa 32 orang responden tidak bekerja, 12 responden masih sekolah dan kuliah sedangkan sisanya 64 responden bekerja sebagai pedagang, karyawan, pegawai negeri sipil, buruh, dan petani. Data diatas menunjukkan bahwa jumlah responden yang bekerja lebih banyak daripada responden yang tidak bekerja. Menurut Wawan dan Dewi (2011), faktor-faktor yang mempengaruhi tingkat pengetahuan adalah pendidikan, pekerjaan, umur, lingkungan dan sosial budaya. Sebagian besar responden penelitian ini bekerja, kondisi ini memungkinkan 
responden untuk lebih banyak berinteraksi dengan orang lain. Dari interaksi-interaksi tersebut memung-kinkan responden memperoleh informasi yang lebih banyak. Hal ini memberi kontribusi yang positif terhadap meningkatnya pengetahuan seseorang terhadap sesuatu hal, dimana dalam penelitian ini terkait dengan pengetahuan tentang kesehatan jiwa

\section{Tingkat Pendidikan}

Berdasarkan data responden, diperoleh informasi bahwa sebagian besar responden yaitu 77 orang $(71,3 \%)$ berada pada kategori pendidikan tinggi.

Menurut UU RI No. 20 Tahun 2003 jenjang pendidikan formal di Indonesia terdiri atas pendidikan dasar, pendidikan menengah, dan pendidikan tinggi .

Dalam penelitian ini peneliti membuat kategori pendidikan menjadi dua yaitu tinggi dan rendah, berbeda dengan kategori pendidikan dalam UndangUndang No. 20 tahun 2003. Sedangkan yang termasuk dalam kategori pendidikan tinggi dimulai dari sekolah menengah atas. Sebagian besar responden dalam penelitian ini masuk dalam kategori pendidikan tinggi. Tingginya pendidikan seseorang akan memberikan pengaruh terhadap pengetahuan seseorang. Seperti yang dipaparkan oleh Wawan dan Dewi (2011), faktor-faktor yang mempengaruhi tingkat pengetahuan adalah pendidikan, pekerjaan, umur, lingkungan dan sosial budaya. Sedangkan menurut Adnani (2011) pendidikan adalah segala upaya yang direncanakan untuk mempengaruhi orang lain baik individu, kelompok, atau masyarakat sehingga mereka melakukan apa yang diharapkan oleh pelaku pendidikan.

Dari paparan tersebut dapat dipahami bahwa melalui pendidikan seseorang akan dipengaruhi untuk bisa melakukan atau menguasai sesuatu. Melalui pendidikan seseorang akan mempelajari banyak hal, menyerap banyak informasi, mengubah persepsi dan membentuk pemahaman yang benar. Senada dengan paparan yang disampaikan oleh Hasbullah (2009) bahwa pendidikan merupakan usaha manusia untuk membina kepribadiannya sesuai dengan nilai-nilai di dalam masyarakat dan kebudayaan.

3. Tingkat Pengetahuan

Berdasarkan data responden, diperoleh informasi bahwa sebagian besar responden yaitu 94 orang $(87 \%)$ mempunyai pengetahuan tentang kesehatan jiwa yang tinggi.

Tingkat pengetahuan seseorang dipengaruhi oleh beberapa hal yaitu pendidikan yang diterima dengan baik dari lingkungan sekolah, keluarga maupun dari orang lain. Bisa diperoleh melalui berbagai media informasi seperti buku, internet dan media massa yang lain. Semakin bertambah usia dan pengetahuan seseorang juga mempengaruhi pola pikir yang semakin berkembang. Hal ini sesuai dengan yang dikemukakan oleh Wawan dan Dewi (2011), bahwa faktor-faktor yang mempengaruhi tingkat pengetahuan seseorang adalah pendidikan, pekerjaan, umur, lingkungan dan sosial budaya.

Dalam penelitian ini sebagian besar responden memiliki tingkat pengetahuan yang tinggi tentang kesehatan jiwa, hal ini dimungkinkan karena pendidikan responden sebagian besar 
setingkat minimal SMA. Menurut Wawan dan Dewi (2011) tingkat pendidikan seseorang akan berpengaruh dalam memberi respon terhadap sesuatu yang datang dari luar. Orang yang berpendidikan tinggi akan memberi respon yang lebih rasional terhadap informasi yang datang dan akan berfikir sejauh mana keuntungan yang mungkin akan mereka peroleh dari gagasan tersebut.

4. Sikap Masyarakat Tentang Gangguan Jiwa

Berdasarkan data yang diperoleh dapat diketahui bahwa 87 orang $(80,6 \%)$ responden mempunyai sikap yang positif terhadap pasien gangguan jiwa.

Notoatmojo (1997) sebagaimana dikutip oleh Wawan dan Dewi (2011) menjelaskan bahwa sikap adalah merupakan reaksi atau respon seseorang yang masih tertutup terhadap suatu stimulus atau objek. Sedangkan menurut Purwanto (1998) sikap adalah pandangan-pandangan atau perasaan yang disertai kecenderungan untuk bertindak sesuai sikap objek. Adapun faktor-faktor yang mempengaruhi sikap menurut Wawan dan Dewi (2011) adalah pengalaman pribadi, pengaruh orang lain yang dianggap penting, pengaruh kebudayaan, media massa, lembaga pendidikan dan lembaga agama serta faktor emosional

Dalam penelitian ini sebagian responden mempunyai sikap positif pada pasien gangguan jiwa. Hal ini dimungkinkan karena responden mempunyai pemahaman yang benar terkait dengan gangguan jiwa dan hal tersebut tidak mengganggu atau bertentangan dengan nilai-nilai pribadinya. Seperti paparan dari Katz (1964) sebagaimana dikutip oleh Wawan dan Dewi (2011) dimana salah satu fungsi sikap adalah fungsi manfaat atau penyesuaian yaitu fungsi yang berkaitan dengan sarana tujuan. Disini sikap merupakan sarana mencapai tujuan. Orang memandang sejauh mana objek sikap dapat digunakan sebagai sarana atau sebagai alat dalam rangka mencapai tujuan. Bila obyek sikap dapat membantu seseorang dalam mencapai tujuannya, maka orang akan bersikap positif terhadap obyek tersebut, demikian sebaliknya bila obyek sikap menghambat dalam pencapaian tujuan, maka orang akan bersikap negatif terhadap obyek sikap yang bersangkutan.

Tingkat pendidikan berkontribusi dalam pembentukan sikap seseorang juga dikuatkan dengan paparan dari Wawan dan Dewi (2011), mengenai ciri-ciri sikap antara lain : sikap bukan dibawa sejak lahir melainkan dibentuk atau dipelajari sepanjang perkembangan itu dalam hubungan dengan obyeknya. Sifat ini membedakannya dengan sifat motif-motif biogenis seperti lapar, haus, kebutuhan akan istirahat. Dari paparan ini dapat dipahami bahwa seseorang memerlukan waktu untuk mempelajari atau mengetahui sesuatu sampai yang bersangkutan mampu memiliki sikap tertentu terhadap suatu hal atau objek.

5. Hubungan Tingkat Pendidikan Dengan Sikap Masyarakat Terhadap Pasien gangguan Jiwa Berdasarkan analisa bivariat dengan uji Chi Square yang dilakukan diperoleh nilai significancy 0.000 , berarti ada hubungan antara tingkat pendidikan dengan sikap masyarakat terhadap pasien gangguan jiwa. 
Menurut Wawan dan Dewi (2011) salah satu faktor yang mempengaruhi sikap adalah lembaga pendidikan dan lembaga agama. Konsep moral dan ajaran dari lembaga pendidikan dan lembaga agama sangat menentukan sistem kepercayaan tidaklah mengherankan jika kalau pada gilirannya konsep tersebut mempengaruhi sikap. Responden dalam penelitian ini sebagian besar $(71,3 \%)$ memiliki tingkat pendidikan yang tinggi, pendidikan tersebut diperoleh dari lembaga pendidikan formal yang ada. Pada saat menempuh pendidikan tentu saja responden mendapatkan pembelajaran yang akan mempengaruhi konsep pikir dan nilai-nilai yang ada pada diri responden.

Hal tersebut sesuai dengan paparan definisi pendidikan dari Ki Hajar Dewantara (1889-1959) sebagaimana dikutip oleh Malik (2013) bahwa pendidikan umumnya berarti daya upaya untuk memajukan budi pekerti (karakter, kekuatan batin), pikiran (intellect), dan jasmani anak-anak selaras dengan alam dan masyarakatnya. Begitu juga menurut Edgar Dalle yang mengatakan bahwa pendidikan merupakan usaha sadar yang dilakukan oleh keluarga, masyarakat, dan pemerintahan melalui kegiatan bimbingan, pengajaran, dan latihan yang berlangsung di sekolah dan di luar sekolah sepanjang hayat untuk mempersiapkan peserta didik agar dapat memainkan peranan dalam berbagai lingkungan hidup secara tetap untuk masa yang akan datang. Kondisi inilah yang akan membentuk sikap responden terhadap suatu hal, dalam hal ini sikap responden terhadap pasien gangguan jiwa. Hal ini juga didukung oleh paparan dari dari
Wawan dan Dewi (2011) mengenai ciri-ciri sikap yaitu :

a. Sikap bukan dibawa sejak lahir melainkan dibentuk atau dipelajari sepanjang perkembangan itu dalam hubungan dengan obyeknya.

b. Sikap dapat berubah-ubah karena itu sikap dapat dipelajari dan sikap dapat berubah pada orang-orang bila terdapat keadaan-keadaan dan syarat-syarat tertentu yang mempengaruhi sikap pada orang itu.

c. Sikap tidak berdiri sendiri, tetapi senantiasa mempunyai hubungan tertentu terhadap suatu obyek dengan kata lain, sikap itu terbentuk, dipelajari atau berubah senantiasa berkenan dengan suatu obyek tertentu senantiasa dapat dirumuskan dengan jelas.

Dari paparan di atas dapat disimpulkan bahwa sikap tidak terbentuk begitu saja tetapi melalui proses yang panjang. Salah satu proses yang berkontribusi dalam pembentukan sikap tersebut adalah pendidikan, karena pada saat menjalani pendidikan seseorang mempelajari sesuatu, mengetahui konsep-konsep tentang sebuah hal dan pada akhirnya pemahaman tersebut akan membentuk sikap seseorang terhadap sebuah objek atau sesuatu hal.

6. Hubungan Tingkat Pengetahuan Tentang Kesehatan Jiwa Dengan Sikap Masyarakat Terhadap Pasien Gangguan Jiwa

Berdasarkan analisa bivariat dengan uji Chi Square yang dilakukan diperoleh nilai significancy 0.000 , berarti ada hubungan antara tingkat pengetahuan tentang kesehatan 
jiwa dengan sikap masyarakat terhadap pasien gangguan jiwa.

Pengetahuan atau kognitif merupakan domain yang sangat penting dalam membentuk tindakan seseorang (overt behavior). (Fitriani, 2011) Sedangkan menurut Notoatmodjo (2011), dari pengalaman dan penelitian ternyata perilaku yang didasarkan oleh pengetahuan akan lebih langgeng daripada perilaku yang tidak didasari oleh pengetahuan. Penelitian Rogers (1974), mengungkapkan bahwa sebelum orang mengadopsi perilaku baru (berperilaku baru), di dalam diri orang tersebut terjadi proses berurutan, yakni:

a. Awareness, (kesadaran) .

b. Interest, (merasa tertarik) Di sini sikap subjek mulai timbul.

c. Evaluation, (menimbangnimbang)

d. Trial (mencoba)

e. Adoption, subjek telah berperilaku baru sesuai dengan pengetahuan, kesadaran, dan sikapnya terhadap stimulus.

Dari paparan di atas dapat diketahui bahwa pengetahuan mendahului atau mendasari seseorang berperilaku. Seseorang akan menyadari (awareness) setelah mengetahui stimulus (objek) terlebih dahulu. Kemudian seseorang akan merasa tertarik (interest) terhadap stimulus atau objek tersebut. Di sini sikap subjek mulai timbul. Dengan demikian sebelum seseorang bersikap terhadap sesuatu maka orang tersebut harus mengetahui objek tersebut lebih dahulu.

Hal tersebut juga sesuai dengan paparan dari Thomas dan Znaniecki (1920) sebagaimana dikutip oleh Wawan dan Dewi (2011) yaitu sikap adalah predisposisi untuk melakukan atau tidak melakukan suatu perilaku tertentu, sehingga sikap bukan hanya kondisi internal psikologis yang murni dari individu, tetapi sikap lebih merupakan proses kesadaran yang sifatnya individual.

7. Hubungan Tingkat Pendidikan dan Tingkat Pengetahuan Tentang Kesehatan Jiwa Dengan Sikap Masyarakat Terhadap Pasien Gangguan Jiwa

Dari uji statistik multivariat dengan regresi logistik yang dilakukan dapat diketahui bahwa terdapat hubungan antara tingkat pendidikan dan tingkat pengetahuan dengan sikap masyarakat pada pasien gangguan jiwa yang ditunjukkan dengan nilai Nagelkerke $R$ Square 0,279 atau 27,9 \%. Variabel tingkat pengetahuan berhubungan positif dan signifikan dengan sikap masyarakat dimana responden dengan tingkat pengetahuan yang tinggi berpeluang 6,8 kali lebih besar untuk memiliki sikap yang positif dari terhadap pasien gangguan jiwa daripada responden dengan tingkat pengetahuan yang rendah

Variabel tingkat pendidikan juga berhubungan positif dan signifikan dengan sikap masyarakat dimana responden yang mempunyai tingkat pendidikan tinggi berpeluang 3,5 kali lebih besar untuk bersikap positif terhadap pasien dengan gangguan jiwa daripada responden yang berpendidikan rendah.

Jika dilihat dari nilai Nagelkerke $R$ Square 0,279 maka dapat diketahui bahwa variabel tingkat pendidikan dan tingkat pengetahuan secara bersamasama mempengaruhi sikap masyarakat terhadap pasien 
gangguan jiwa sebesar 27,9 \%, sedangkan sisanya $72,1 \%$ sikap masyarakat dipengaruhi oleh variabel lain. Hasil penelitian ini dapat dipahami karena selain tingkat pengetahuan dan tingkat pendidikan, sikap dipengaruhi oleh hal -hal yang lain, seperti yang dipaparkan oleh Wawan dan Dewi (2011), yakni faktor-faktor yang mempengaruhi sikap adalah:

a. Pengalaman pribadi

b. Pengaruh orang lain yang dianggap penting

c. Pengaruh kebudayaan

d. Media massa

e. Lembaga pendidikan dan lembaga agama

f. Faktor emosional

Hasil penelitian ini sesuai dengan penelitian yang dilakukan oleh Nondyawati (2015) yang berjudul "Hubungan Pengetahuan dan Sikap dengan Motivasi Keluarga dalam Memberikan Dukungan pada Klien Gangguan Jiwa". Dimana hasil penelitian tersebut menunjukkan hubungan kuat faktor pengetahuan dan sikap dengan motivasi yang ditunjukkan dengan ( $\alpha$ hitung $)=0,000$ dan korelasi $r=0,750$ dan ( $\alpha$ hitung $)=$ 0,000 dan korelasi $r=0,765$. Begitu juga dengan hasil penelitian dari Sulistyorini (2013) yang berjudul "Hubungan Pengetahuan tentang Gangguan Jiwa Terhadap Sikap Masyarakat Kepada Penderita Gangguan Jiwa di Wilayah Kerja uskesmas Colomadu 1". Dimana dari hasil penelitian ini diketahui terdapat hubungan yang signifikan antara pengetahuan tentang gangguan jiwa terhadap sikap masyarakat kepada penderita gangguan jiwa, ditunjukkan dengan nilai koefisien korelasi $(\mathrm{T})$ sebesar 0,347 dengan nilai signifikansi ( $p$-value) 0,000 .
8. Keterbatasan Penelitian

Dalam penelitian ini, peneliti tidak melakukan pembatasan terhadap variabel-variabel lain yang bisa mempengaruhi sikap responden terhadap pasien gangguan jiwa. Dan faktor-faktor lain yang berpengaruh tersebut tidak dimasukkan dalam kuesioner penelitian sehingga kemungkinan hasilnya belum bisa diketahui. Karena tidak ada data yang mendukung sehingga harus dilakukan penelitian lagi apabila ingin mengetahui variabel lain yang berpengaruh terhadap sikap masyarakat terhadap pasien gangguan jiwa.

\section{KESIMPULAN}

1. Tingkat pendidikan masyarakat di RW XX Desa Duwet Kidul, Kecamatan Baturetno, Kabupaten Wonogiri adalah berpendidikan tinggi sebanyak 77 orang $(71,3 \%)$ dan berpendidikan rendah sebanyak 31 orang $(28,7 \%)$

2. Tingkat pengetahuan masyarakat tentang kesehatan jiwa di RW XX Desa Duwet Kidul, Kecamatan Baturetno, Kabupaten Wonogiri adalah tingkat pengetahuan yang tinggi sebanyak 94 orang $(87 \%)$ dan tingkat pengetahuan yang rendah sebanyak 14 orang (13 $\%$ ).

3. Sikap masyarakat di RW XX Desa Duwet Kidul, Kecamatan Baturetno, Kabupaten Wonogiri terhadap pasien gangguan jiwa adalah yang bersikap positif sebanyak 87 orang $(80,6 \%)$ dan yang bersikap negatif sebanyak $21(19,4 \%)$

4. Ada hubungan tingkat pendidikan dengan sikap masyarakat terhadap pasien gangguan jiwa di RW XX Desa Duwet Kidul, Kecamatan Baturetno, Kabupaten Wonogiri 
yang ditunjukkan dengan nilai significancy 0,000 .

5. Ada hubungan tingkat pengetahuan dengan sikap masyarakat terhadap pasien gangguan jiwa di RW XX Desa Duwet Kidul, Kecamatan Baturetno, Kabupaten Wonogiri dengan nilai significancy 0,000 .

6. Masing-masing variabel secara bersama-sama mempengaruhi sikap masyarakat RW XX Desa Duwet Kidul, Kecamatan Baturetno, Kabupaten Wonogiri terhadap pasien gangguan jiwa sebesar 27,9 \%, sedangkan sisanya $72,1 \quad \% \quad$ sikap dipengaruhi oleh variabel lain.

\section{SARAN}

1. Bagi Masyarakat

Pengetahuan dan sikap masyarakat yang positif terhadap pasien gangguan jiwa diharapkan dapat menjadi dasar dalam menerima dan merawat pasien gangguan jiwa yang ada di masyarakat dengan benar dan meningkatkan kesehatan jiwa masyarakat melalui pembentukan kader kesehatan jiwa dan pembentukan desa siaga sehat jiwa.

2. Bagi Peneliti Selanjutnya

Melakukan penelitian lanjutan terkait dengan variabel lain yang bisa mempengaruhi sikap masyarakat, mengingat tingkat pendidikan dan tingkat pengetahuan hanya mempunyai pengaruh terhadap sikap kurang dari $30 \%$.

\section{DAFTAR PUSTAKA}

Fitriani, Sinta. 2011. Promosi Kesehatan. Graha IImu, Yogyakarta.

Hidayat, A. Azis Alimul. 2008. Riset Keperawatan dan Teknik Penulisan Ilmiah. Salemba Medika, Jakarta.
2009. Riset Keperawatan dan Teknik Penulisan IImiah. Salemba Medika, Jakarta.

Malik, H. Fajar. 2003. Kebangkitan Pendidikan Daerah tertinggal. LP3ES, Jakarta.

Notoatmodjo, Soekidjo. 2007. Promosi Kesehatan dan IImu Perilaku. Rineka Cipta, Jakarta.

. 2011. Kesehatan Masyarakat IImu dan Seni. Rineka Cipta, Jakarta.

Suliswati, et al. 2015. Konsep Dasar Keperawatan Kesehatan Jiwa. Kedokteran EGC, Jakarta.

Putra, Sitiatava Rhizema. 2012. Panduan Riset Keperawatan dan Penelitian IImiah. Medika, Yogyakarta.

Suyanto. 2011. Metodologi dan Aplikasi Penelitian Keperawatan. Mulia Medika, Yogyakarta.

Undang-Undang Republik Indonesia Nomor 20 Tahun 2003. Sistem Pendidikan Nasional.

Wawan, A dan Dewi M. 2011. Teori dan Pengukuran Pengetahuan Sikap dan Perilaku Manusia. Mulia Medika, Yogyakarta.

Yusuf, Ah, Rizky Fityasari PK dan Hanik Endang Nihayati. 2015. Buku Ajar Keperawatan Kesehatan Jiwa. Salemba Medika, Jakarta.

Yosep, H. lyus dan Titin Sutini. 2014. Buku Ajar Keperawatan Jiwa. PT Refika, Bandung. 
Sulistyorini. 2013. "Hubungan Pengetahuan Tentang Gangguan Jiwa Terhadap Sikap Masyarakat Kepada Penderita Gangguan Jiwa di Wilayah Kerja Puskesmas Colomadu". URL: http://eprints.ums.ac.id/25557/ 13/Naskah Publikasi.pdf.

Diakses tanggal 10 November 2015
Nondyawati, Kiky Afathul. 2015. "Hubungan Pengetahuan dan Sikap dengan Motivasi Keluarga Dalam Memberikan Dukungan pada Klien Gangguan Jiwa". URL: https://lppmunigresblog.files.w ordpress.com/2015/06/kikyalifathul-nondyawati.pdf. Diakses tanggal 10 November 2015

1 Dosen AKPER Panti Kosala Surakarta

2 Mahasiswa AKPER Panti Kosala Surakarta 